\title{
The Abject and the Oedipal in Sonya Hartnett's Sleeping Dogs
}

\author{
Joanne McPherson
}

$\mathrm{O}$ the jacket cover of Sleeping Dogs we are told by Robert Cormier that with this novel 'Sonya Hartnett has truly pushed the boundaries of YA literature to their outer edges and perhaps beyond...' One can only wonder at what hovers beyond that precipice as we encounter the seven members of the eccentric Willow family: Griffin the abusive and dictatorial father; Grace, the absentee maternal figure whose overwhelming inertia facilitates Griffin's abusive habits; Edward, the eldest of the Willow children; Michelle, who is relentlessly narcissistic; Jordan, the romantically fragile artist whose difference makes him the target of Griffin's abuse; Oliver, who craves friendship and normalcy, and Speck, who is both sadist and voyeur. With heavy-handed symbolism this novel frames an abject incestuous relationship between siblings Jordan and Michelle within the context of their Oedipal desires. The result is problematic in its reassertion of the dominant ideological paradigms as Griffin, who constantily reaffirms the power of patriarchal control, literally gets away with murder.

Julia Kristeva's theory of abjection provides an interesting reading of Sleeping Dogs, for each of the characters in some way embodies the abject. Many children's novels feature abject characters, from Lewis Carroll's Alice in Alice in Wonderland, whose body becomes a distorted site of inconstant size, to Roald Dahl's witch in The Witches, who embodies abject female sexuality as she "not only rejects the Judeo-Christian construction of woman as procreator but transgresses it totally in that she wishes to murder children (Bird 1998, p. 125). In Sleeping Dogs abjection is apparent in the construction of Jordan and Michelle's incestuous relationship; in the representation of Grace as the alienating maternal figure; in the slaughter of animals and the murder of the son; and in the degeneration of Bow Fox during the Christmas hunt from the state of meddlesome outsider to inarticulate abjection. In the world of Bonaparte Farm different kinds of abjection are given different levels of ideological currency, for whilst Kristeva recognises that murder and incest are equally abject in the eyes of both secular and religious institutions it is the defiance of the word, the Father, the symbolic and patriarchal, through the performance of incest, which is punished in Sleeping Dogs, and not the murder of the son.
However, to attempt an analysis of Sleeping Dogs through Kristeva's interpretation of the abject one must first have a clear understanding of the theory itself. In Powers of Horror Julia Kristeva establishes a psychoanalytic methodology for the explication and elaboration of abjection. Beginning with a consideration of the theory of the subject and the absence of abjection in the preOedipal stage Kristeva maps the physical and psychical development of the subject from 'an abject borderline state' (Smith 1996, p.149) in which 'I' exist before the acquisition of language or the acceptance of objective coherence to 'my' location as a speaking subject within the symbolic order (Grosz 1990, p.80). Kristeva states that abjection

\section{preserves what existed in the archaism of pre- objectal relationship, in the immemorial violence with which a body becomes separated from another body in order to be - maintaining that night in which the outline of the signified thing vanishes and where only the imponderable affect is carried out.}

(1982, p. 10)

Thus, the ability to take up a symbolic position as a social and speaking subject is predicated upon the subject's rejection of the borderline, the unpredictable, the ambiguous and the unclean.

Essential to Kristeva's essay on abjection is the Oedipal myth which provides a narrative of gender construction based upon the child's sex and concrete corporeality. Freud's Oedipus complex posited the theory that the first object identified by the child is the mother upon whom the child is dependant. With a developing subject identity the male child desires the mother, 'it is easy to see that the little man wants his mother all to himself, finds his father in the way, becomes restive when the latter takes upon himself to caress her, and shows his satisfaction when the father goes away or is absent' (Freud 1936, p.279). Kristeva accepts this theory as central to her argument on the development of subject identity and then expands upon it to suggest that prior to the development of subject identity there is a movement toward expelling or rejecting the mother, until she ambiguously represents both 'loveobject' (Freud 1936, p.277) and the abject m/Other. 
Abjection is, therefore, a result of the separation of the maternal/child bond in an act which ensures that the mother, by representing at the pre-symbolic level the prototype of what the drives expel (Lechte 1990, p.159), becomes abject: 'The abject would thus be the 'object' of primal repression' (Kristeva 1982, p.12).

Kristeva writes that the transition from pre-Oedipal status to stable subject identity is accompanied by the acquisition of language and thus an acceptance of the symbolic order: 'A representative of the paternal function takes the place of the good matemal object that is wanting. There is language instead of a good breast. Discourse is being substituted for maternal care, and with it a fatherhood belonging more to the realm of the ideal than of the superego' (Kristeva 1982, p.45). In adopting the Oedipal myth Kristeva fails to challenge the symbolic order, or its implicit gender oppositions, bound as she is by this heterosexual, patriarchal discourse of differences and oppositions. Criticism has often been levelled at Kristeva for situating the mother as central to the concept of abjection, and thus ambiguity and perversion, whilst locating sperm, and thus the masculine, as having no 'polluting value' (Kristeva 1982, p.71). According to Mary Caputi, 'many feminist scholars interpret [Kristeva's] Powers of Horror and Tales of Love as blatant capitulations to the status quo, writings which buy into masculinist principles, endorse patriarchal structures, and have lost any political edge' (1993, p.32).' Such objections, it has been argued, are often themselves premised upon a simplistic, conservative equation between masculinity and culture (or the 'symbolic') ruling out the possibility of identifying 'masculinity' with the 'maternal' (Soper 1990, p.239). However, as Kate Soper argues 'it is precisely this transformability of cultural codings and norms which is ruled out by a theory premised upon the permanence of their existing meanings' (1990, p.239). Thus, the polarisation of the imaginary father and the abject mother of Kristeva's theory does little to challenge the gendered paradigms that underpin the psychoanalytic discourses she appropriates (Grant 1997, p.166).

In Powers of Horror Kristeva states that abjection appears 'as a rite of defilement' (p.17) in which corporeal boundaries and the borders of identity are threatened, rendered indistinct and ambiguous (Lechte 1990, p.163). She writes that it is not "lack of cleanliness or health that causes abjection but what disturbs identity, system, order. What does not respect borders, positions, rules. The inbetween, the ambiguous, the composite' (Kristeva 1982, p.4). Hence, menstrual blood, hair, vomit and excrement are all situated as ambiguous and thus abject: 'Contrary to what enters the mouth and nourishes, what goes out of the body, out of its pores and openings, points to the infinitude of the body proper and gives rise to abjection.' (Kristeva 1982, p.108) Of central importance to the concept of abjection is the notion that the void, the expulsion, the excretion, the improper and unclean are all disordered features of corporeal existence that, whilst being adamantly rejected, are impossible to exclude. Elizabeth Grosz writes:

what must be expelledfrom the subject's corporeal
functioning can never be fully obliterated but
hovers at the borders of the subject's identity,
threatening apparent unities and stabilities with
disruption and possible dissolution ... [I]t is
impossible to exclude the threatening or anti-
social elements with any finality.

(1990, p.87)

In reaction to the threat the abject poses to corporeal, egoistic, social and subconscious boundaries various modes of control have been established to distance it from the symbolic order. According to Kristeva, this is the function of numerous secular and religious rituais and codes that constantly reaffirm the separation of the subject and the abject: 'For abjection, when all is said and done, is the other facet of religious, moral, and ideological codes on which rest the sleep of individuals and the breathing spells of societies. Such codes are abjection's purification and repression' (Kristeva 1982, p.209). Many religious texts, including the Bible, clearly situate the abject as abomination and institute rituals and acts of purification which in turn reaffirm the imposition of 'the logic that sets up the symbolic order' (Kristeva 1982, p.110). Consider the incestuous relationship, particularly that between biological parent and child or between siblings. According to Freud, 'Psycho-analytic investigations have shown beyond the possibility of 
doubt that an incestuous love-choice is in fact the first and the regular one, and that it is only later that any opposition is manifested toward it ...' (1936, p.177). Opposition to incestuous relationships comes in many forms including social taboo, legal prohibitions and religious dictum, which are further supported through a system of rituals, sacred rites and acts of purification. Kristeva writes that, '[d]efilement is incest considered as transgression of the boundaries of what is clean and proper' (1982, p.85).

From this methodology we can plot the emergence of abjection as it relates to incest and Oedipal desire in Sonya Hartnett's novel Sleeping Dogs. It is worth noting again that the appearance of abjection in this text arises in numerous characterisations and incidents; however, the limitations of this particular paper preclude a discussion of al! these cases of abjection. Thus this paper will discuss the appearance of abjection, with particular reference to the characterisation of the maternal and the depiction of incestuous desire, as each relates to the Oedipal drama central to Kristeva's theory.

In adopting the Freudian Oedipal complex as signifier of the separation of the maternal/child bond and thus the establishment of subjective identity in the symbolic order, Kristeva ultimately situates the maternal as abject: 'Mother and death, both abominated, abjected, slyly build a victimizing and persecuting machine at the cost of which I become subject of the Symbolic as well as Other of the Abject' (Kristeva 1982, p.112). In Sleeping Dogs Grace embodies this site of abjection. Her face is marked with 'a rat's nest of age lines and broken veins' (Hartnett 1995 , p.116) and her stultifying inertia, a reflection of her powerlessness in the face of Griffin's overwhelming authority, inhibits all maternal acts until her world is encompassed by the living room in which she resides appeased only by the sight of her favourite teapot. In a room in which she shuns 'wind, rain, light and fresh air' (p.16), where the 'curtains have remained closed for so long that generations of spiders have laced together their folds' (pp.16-17), Grace relies upon her children to feed and take care of her. This inversion of the maternal/child role further alienates her children who believe her to be 'tragic and mad' (p.17). Unable to understand or explain Grace's inertia, Oliver tells Bow Fox that she is 'just tired' (p.66).

This is his excuse for Grace and it is what he makes himself believe, for he is incapable of fathoming any other reason for his mother's withdrawal from life. He loves her and does not begrudge her inability to care for him as another mothermight, as he remembers she once managed to care for him, but sometimes the thought of her makes him fretful, and sometimes she scares him in the smallest way.

(p.66-67)

To her children Grace embodies the horror of matemity. Through the eyes of the stranger, Bow Fox, she is a 'small and very feeble old woman' (p.52) who appears 'discoloured' ( $p .66$ ) in the darkness of the lounge room. But, more than this, Grace is both mad and powerless in the face of Griffin's sovereignty. When the burdens of her maternal responsibilities became too much, when the care of husband and children 'had become more than she could bear', Grace had 'sunk into her chair, praying that the farm would run, for a time, without her' (p.15). Whilst this quiet transition from supporter and nurturer to passive observer might be read as a method of resisting the patriarchal order, for Grace it was simply an act of abdication in which the little power that she did exert within and over her family was surrendered. 'In her chair her mind travelled and travelled until it reached a quiet, dim place that she found greatly to her liking. She has stayed in this place for many years' (p.15). In this ambiguous state, between stupor and consciousness, Grace embodies abjection.

One of the few topics of conversation that will raise Grace from her apathetic state is a discussion of the birth of her children and her need to constantly return to this topic both fascinates and repels them.

Speck is the youngest member of her family, and she likes her mother to tell the story of her birth. Her mother recounts this event well: Speck, she says, came gagging with her cord around her neck, as blue as a lolly from a country fair showbag. Speck likes this simile, she tikes the story. She likes to know her mother remembers 
anything about her existence at all. Grace had her tubes tied after Speck's birth and the idea can make Speck splutter with laughter or crawl with guilt, suspecting herself somehow responsible for her mother's knotted guts.

(p.9-10)

This repeated story is a constant reminder to Grace's children that she is the site of abjection from which the grotesquely discoloured child flows. In a further sign of alienation we discover that the children experience both humour and guilt when contemplating the invasive surgical operation Grace underwent, that entailed the displacement of her corporeal boundaries, to achieve 'knotted guts' and thus ensure her inability to procreate further.

More than any of her other children it is Michelle who is most alienated from Grace. It is upon Michelle's shoulders that Grace's responsibilities now fall and her sense of abandonment and resentment inflects their stumbling relationship.

For some years the conversation between mother and daughter has been rudimentary. Michelle ... will not accept or forgive or make the slightest attempt to sympathise with Grace's decline ... Although she lets no one see it, she scorns her mother as pathetic.

(p.77)

Grace's abandonment of the traditional maternal roles and duties results in the transfer of these responsibilities to Michelle and facilitates Grace's status as the matemal abject, which is borne out in the alienation and scorn of her husband and children. Her 'slowing', or deterioration into her psychological abyss, results in a concurrent degeneration from adult status to troublesome and irritating 'child' (p.79). Finally we are told that Grace's attempts to gain her daughter's attention and aid resemble 'a feeble mewiing cry that comes through the wall like the noise of a newborn kitten' (p.77), a reminder to the audience of the earlier 'damp body' of a newborn kitten found dead by Oliver's inquisitive toes burrowing through a hole in the floor (p.6). In this parallel, Grace's inertia links her body to the kitten whose existence was once perilously situated on the borders of life and death. Grace, we may thus assume, is little better than the abject corpse that lies outside the symbolic order and thus threatens its rules, its systems. Like Kristeva's 'criminal with a good conscience, the shameless rapist, the killer who claims he is a saviour', Grace is ambiguousiy and abjectly positioned as the selfabsorbed mother (Kristeva 1982, p.4). She is both essential to each child's sense of individuation and position within the symbolic order and a reminder of the fragile mental and corporeal borders that stabilize their positionality.

Michelle's alienation from her mother can be read as a result of her anger and dissatisfaction with their relationship and an effect of the Oedipal complex. In rejecting her mother Michelle is constantly re-enacting her separation from the maternal abject in what Lacan terms 'a means of masking, of parrying the fundamental fund of anguish' (Lacan as cited by Kristeva 1982, p.33), which results from 'the deprivation of the breast [and] an imaginary frustration of the gift as a maternal relation ...' and in substitution for this relation Michelle turns to the symbolic, the paternal (Kristeva 1982, p.32). Evidence of Michelie's devotion to her father is apparent throughout the text; even the unwelcome stranger Bow Fox can identify, if not name, the Oedipal complex at work within Michelle and Griffin's relationship. In a conversation with Oliver, Bow explains Griffin's favouring of and apparent attraction to Michelle and his intense antipathy toward Jordan, who is effectively his competition for Michelle's love: "Fathers are supposed to like their giris best, aren't they? Their precious, pretty girls. And they're supposed to be much tougher on the boys, revenging their sense of failure through them - isn't that how it goes?" (p.69) Griffin's adoration of Michelle, whilst platonic, is an underlying motivation for much of the abuse throughout the novel. By focusing upon Jordan as the primary victim of his abusive tendencies Griffin identifies his competitor for Micheile's love and in accepting Griffin's abuse as his due punishment for Michelle's sexual attention, Jordan simply reinforces this Oedipal drama.

Jordan, too, is particularly devoted to his mother. This is the first of many characteristics that set Jordan apart from the rest of his family. Unlike all the other black haired Willow children Jordan's hair is 'yellow as corn.... This 
makes Jordan a favourite with his mother and attracts his father's evil eye.' (p.11-12) Jordan is the only Willow child who has the patience to deal with his mother as he fetches her favourite teapot and telis her the events of the day. His individuality is also evident in his talents as an artist, an apparently impractical activity on a farm where survival seems to be of greatest concern. Whilst the covert sexuality that underpins Michelle and Griffin's relationship is not evident in Jordan's relationship with his mother, Grace, his devotion to her sets him apart from his siblings and infers an ongoing connection to their preObjectal relationship. Griffin's antipathy toward Jordan is exacerbated by each of these marked differences and by his fear that Jordan is not his biological son. Ultimately this Oedipal hostility, in which the desire for daughter and mother are bound between the relationship of father and son, results in murder.

'The symptom: a language that gives up, a structure within the body, a non assimilable alien, a monster, a tumor, a cancer that the listening devices of the unconscious do not hear, for its strayed subject is huddled outside the paths of desire.... In the symptom, the abject permeates me, I become abject. Through sublimation, I keep it under control. The abject is edged with the sublime' (Kristeva 1982, p.11). Following the Freudian path of Oedipal desire Jordan and Michelle, both sexually and emotionally unfulfilled by their parental Oedipal relationships, turn to one another for solace: 'A boy may take his sister as love-object in place of his faithless mother ... A little girl takes [a] brother as a substitute for the father ...' (Freud 1936, p.281). Thus, their incestuous relationship, their abject or perverse attraction is as much about their familial and biological connection as it is about their upbringing. According to Jordan, '[n]o other body could be as harmonious to him as Michelle's, no one would ever fold around him so comfortably, none could wrap him so perfectly, for Shelly and he are made alike' (pp.59-60). Jordan and Michelle's incestuous relationship, predicated upon the selection of a partner who is 'made alike', is situated in the realms of narcissism. Kristeva writes that the symbolic functions to prohibit the maternal body as a defence against auto-eroticism and incest, however, this prohibition is at best unstable and at times simply functions to remind the subject of the abject
Other: 'Narcissism then appears as a regression to a position set back from the other, a return to a selfcontemplative, conservative, self-sufficient haven' (Kristeva 1982, p.14)

The incestuous relationship between Jordan and Michelle is situated problematically within the text as an act of both abjection and innocence. According to Robert Cormier, Sleeping Dogs ambiguously posits 'sin [a]s somehow innocent ...' (Cormier on cover of Hartnett 1995). This oxymoronic concept of innocent $\sin$ is based upon the apparent ignorance that permeates Jordan and Michelle's relationship but fails to account for their awareness of the wrong they are committing:

It is not something they often talk of: they know what they do is said to be wrong and yet certainly it appears to hurt no one. It causes no trouble and no great punishment comes down from the sky to blight them. Griffin hitting Jordan provides the penalty they don't want but know they probably deserve despite everything they endure, the monotony, the seclusion, the occasional misery of the farm. Denied the chance to do so as children, they are now both incapable of making outside friends: their closeness brings solace and companionship and seems only just.

(pp.58-59)

Their justification for what they both recognise as 'sinful' acts, evident in their expectation that something may 'come down from the sky to blight them', is the belief that their relationship is just reward for suffering the domineering and abusive tendencies of their father. Yet, there is no clear prohibition, no statement of taboo against incest within the limited social, familial and institutional frameworks that comprise the lives of the Willow children. All their siblings know and implicitly condone Jordan and Michelle's relationship. Their knowledge facilitates this affair as all of the children work to deceive their father about the circumstances and nature of this connection and punish Bow Fox when he threatens exposure. However, there is a residual sense of wrongdoing that permeates Jordan and Micheile's affair and it is for this reason that Jordan, in punishment for their acts of defilement 
and abjection, accepts his father's abuse:

Sometimes when his father hits him it strikes [Jordan] as ludicrous, twenty years old and still being hit. So once he'd hit back, had, to his embarrassed astonishment, knocked his father off his feet. He was eighteen then. Michelle had been angry for days. She said to him, 'That was the most disgusting thing I've ever seen, Jordan.' And then she'd sat beside him and said that, in a way, they deserved to be hit, both of them. They knew what they did wasn't right: you read about it in books and it was never right in them. If Griffin hit Jordan, wasn't that a sort of punishment for them? And if they were being punished, didn't that give them freedom to go on doing what they did? 'Do you see what I mean, Jordan?' she'd asked. 'Sometimes, two wrongs can make a right. Can give you a right'.

(p.18)

Michelle's reaction is typical of her selfishness, for Griffin only threatens her with abuse upon exposure for their affair, and even then Michelle dissuades him from punishing her by blaming the affair on Jordan. Therefore, the punishment for their incestuous relationship falls wholly upon Jordan's shoulders and Michelle escapes physicaliy unscathed. Michelle appears to control the incestuous relationship much as Griffin tyrannizes his family, for when her advances are rebuffed she too takes to hitting Jordan. In one encounter Michelle seeks out Jordan, who is sleeping, and attempts to awaken him:

His pillow has fallen from the bed and he lies with his cheek against his hand. The bruises he'd got because a cow had died have almost faded to nothing and he looks clean and young and peaceful. She shakes his shoulder, twitches his hair, pinches his ribs, finally strikes him over the head, but he will not be woken and she is forced to leave him alone.

(p.119)

Michelle leaves this encounter 'peeved' and her aggressive, indeed abusive, acts pass as a typical even habitual characteristic of this relationship (p.119).
The incestuous relationship between Jordan and Michelle is abject. Their ignorance, whilst inhibiting a clear knowledge of the reasons, does not prevent them from acknowledging they are committing a wrong, a sin. Hartnett ensures that their relationship is positioned as abject by locating their meetings as clandestine and illicit, from which follows a strong sense of wrongdoing. Even Bow Fox, the outsider, the temporary interloper recognises this. Disdained by the Willow children and yet held to have a more extensive knowledge of things beyond the farm, especially by Oliver, Bow reacts to the news of Jordan's abuse at the hands of his father by saying: 'the whole thing sounds bloody peculiar... It's wrong, that is: it's weird and it's wrong-' (p.70). Bow's strong and vehement reaction to both the incestuous relationship and parental abuse within the Willow family positions both these deeds as abject, for he recognises the religious, moral and legal taboos that are challenged by these acts. Yet, Bow's position is undermined because of the shallowness of his personal motives and his selfinterested reasoning. His belated attempt to stop the incestuous relationship bears the hallmarks of his vested sexual interest in Michelle, his jealousy of Jordan's artistic talents, and his desire for personal revenge.

According to Kristeva 'religious prohibitions, which are above all behaviour prohibitions, are supposed to afford protection from defilement ...' (Kristeva 1982, p.70), yet it is made clear throughout Sleeping Dogs that the Willow children have lived all of their lives in a 'Godless world' (p.122). More than this, however, the Willow children exist on the parameters of the secular world. Without the education and socialisation offered to other children their only influences are the transient caravanners, the books their father forces them to read, and their family. At the pinnacle of this insular world stands Griffin as sovereign of family and home. Griffin's repeated invocation of 'God' when he challenges Michelle with the information that she had been having an affair with Jordan, represents more than a reference to the deity. In the Willow family Griffin is the Father, with all the significance of the symbolic and the paternal but lacking the sense of the sacred and sublime. Thus, when Griffin claims that Michelle and Jordan have committed a 'sin against God ... spitting in God's eye -' (p.122) he recognises their 
actions as an insult to his authority. Like all his previous abusive actions Griffin turns again to Jordan as the ultimate perpetrator of this insult and like the classic tale upon which the psychoanalytical theory is based the Oedipal battle played out between Griffin and Jordan ultimately culminates in murder. However, unlike the classic tale, the Oedipal drama that surrounds the Willow family concerns the love of a daughter/sister and culminates in the murder of the son.

At the end of Sleeping Dogs the reader, remembering Cormier's comment on the cover of the novel, might well question what boundaries this text has challenged, for we find in the concluding pages the resurrection of the status quo and the reaffirmation of patriarchal power. Far from challenging boundaries this novel continues to reflect the binary positionality upon which Kristeva's argument is reliant, as the powerless and abject maternal figure stands in constant, inadequate opposition to the paternal, rulegoverning symbolic order. Incest is not sanctioned, but rather is vilified as the ultimate crime against the Father and the symbolic, for which Jordan pays with his life. The abject and the Oedipal in Sleeping Dogs are again renounced as sites of perversion and are thus rejected, cleansed, eliminated through the sacrificial destruction of the deject who stood at the crossroads of phobia, obsession and perversion' (Kristeva 1982, p.45). The novel culminates in the delusions of the repentant Bow Fox as he returns to a deserted Bonaparte Farm and imagines the Willow family leaving the farm, "deserting as quickly as they could ... Griffin leading the way in the truck, Edward following in the station wagon, perhaps ... Jordan trailing him at the wheel of the cranky little utility ...' (p.130). These delusions are not shared by the audience who know Jordan's fate and who are ultimately witness to the reaffirmation of patriarchal power and control as Griffin gets away with murder.

\section{NOTES}

1.See also: Ann Rosalind Jones (1984), 'Julia Kristeva on Femininity: The Limits of a Semiotic Politics', Feminist Review 18: 56-73; Jacqueline Rose (1986) 'Julia Kristeva - Take Two', Sexuality in the Field of Vision (New York, Verso Press) pp. 141-164; Jennifer Stone (1983) 'The Horrors of Power: A
Critique of "Kristeva"', The Politics of Theory. Proceedings of the Essex Conference on the Sociology of Literature, July 1982 (Colchester, University of Essex) pp. 38-48.

\section{REFERENCES}

Bird, Anne-Marie (1998) 'Women Behaving Badly: Dahl's Witches Meet the Women of the Eighties', Children's Literature in Education 29.3: 119-129.

Caputi, Mary (1993) 'The Abject Matemal: Kristeva's Theoretical Consistency', Women and Language 16.2: 32-38.

Fletcher, John and Benjamin, Andrew, eds. (1990) Abjection, Melancholia and Love: The Work of Julia Kristeva. London: Routledge.

Freud, Sigmund (1936) Introductory Lectures on PsychoAnalysis: A Course of Twenty-Eight Lectures Delivered at the University of Vienna. 2nd edition. trans. Joan Riviere, London: Allen \& Unwin.

Grant, Megan (1997) 'A Day with Julia Kristeva: Arts, Ethics, Philosophy, Politics', Melbourne Journal of Politics 24.24: 166.

Grosz, Elizabeth (1990) 'The Body of Signification', Abjection, Melancholia and Love: The Work of Julia Kristeva. ed. John Fletcher and Andrew Benjamin. London, Routledge.

Hartnett, Sonya (1995) Sleeping Dogs. Ringwood, Vic: Penguin.

Jones, Ann Rosalind (1984) 'Julia Kristeva on Feminity: The Limits of a Semiotic Politics', Feminist Review 18: $56-73$.

Kristeva, Julia (1982) Powers of Horror: An Essay on Abjection. trans. Leon S. Roudiez. New York, Columbia U.P.

Lechte, John (1990) Julia Kristeva. London, Routledge.

Rose, Jacqueline (1986) 'Julia Kristeva - Take Two', Sexuality in the Field of Vision. New York, Verso Press, pp.141-164. 
Scutter, Heather (1999) Displaced Fictions: Contemporary Australian Fiction for Teenagers and Young Adults. Melbourne, Melbourne U.P.

Smith, Anna (1996) Julia Kristeva: Readings of Exile and Estrangement. London, Macmillan.

Soper, Kate (1990) Troubled Pleasures: Writings on Politics, Gender and Hedonism. London, Verso.

Stone, Jennifer (1983) 'The Horrors of Power: A Critique of "Kristeva", The Politics of Theory. Proceedings of the Essex Conference on the Sociology of Literature, July 1982. Colchester, University of Essex, pp. 38-48.

\section{$\rightarrow$ P.EK}

\section{BYOGRAPHICAL NOTE}

Joanne McPherson completed her Honours degree at the University of Wollongong. She is currently completing a $\mathrm{PhD}$ at the University of New England on the construction of gender and sexuality in modern Australian children's literature.

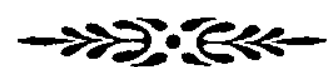

